УДК 59.104+615.9]-001.5

\title{
ЗМІНИ ПОКАЗНИКІВ БІОЕНЕРГЕТИЧНИХ ПРОЦЕСІВ ЗА УМОВ ОДНОЧАСНОГО УРАЖЕННЯ ЩУРІВ ТОКСИЧНИМИ ДОЗАМИ АДРЕНАЛІНУ TА ТЕТРАХЛОРМЕТАНУ
}

\author{
ОК. О. Алексевич, Л. С. Фіра, О. І. Грималюк \\ ДВНЗ «Тернопільський державний медичний університетімені І. Я. Горбачевського МОЗ України» \\ РЕЗЮМЕ. Встановлено, що одночасне ураження щурів тетрахлорметаном та адреналіном викликає посилення \\ процесу глікогенолізу, на що вказує підвищення вмісту глюкози та зниження вмісту глікогену в органах тварин. \\ Протягом експерименту нами відмічено зниження активностей сукцинатдегідрогенази та цитохромоксидази, що \\ свідчить про пригнічення біоенергетитчних процесів в організмі щурів після ураження. \\ КЛЮЧОВІ СЛОВА: тетрахлорметан, адреналін, глюкоза, глікоген, сукцинатдегідрогеназа, цитохромоксидаза.
}

Вступ. До п'ятірки лідерів у структурі захворюваності і смертності населення Укра ни впродовж останніх років незмінно належать як серцево-судинні захворювання, так і захворювання гепатобіліарно системи, зокрема печінки. В умовах науково-технічного прогресу, зростаючого техногенного токсичного забруднення навколишнього середовища, інтенсифікаці темпів життя та стресового навантаження на організм сучасно людини в практиці лікаря все частіше зустрічається поєднання токсичного ураження печінки та серцевосудинно патологі $[3,6]$. Це пояснює необхідність детального вивчення клітинно-молекулярних ланок патогенезу таких коморбідних станів, що дозволить знайти нові точки прикладання для діагностики та лікування дано патологі.

Дані літератури свідчать про формування енегродефіцитних станів при токсичному ураженні печінки, що відображається підвищеними витратами субстратів гліколізу та глікогенолізу - глюкози та глікогену [8]. У випадку впливу адреналіну на вуглеводний обмін відбувається активація процесу глікогенолізу. Водночас як при ураженні печінки, так і при патологічно посиленому адренергічному впливі відбувається пригнічення процесів тканинного дихання [8]. Саме тому нас зацікавив характер взаємоді вищезгаданих патологічних факторів при впливі на перебіг біоенергетичних процесів в організмі в умовах експерименту.

Метою даного дослідження 6 вивчення динаміки біоенергетичних показників в умовах поєднаного гострого ураження міокарда підвищеними дозами адреналіну та токсичного тетрахлорметанового ураження печінки.

Матеріали і методи дослідження. Експерименти виконано на 24 нелінійних білих щурахсамцях масою 170-200 г, яких утримували на стандартному раціоні віварію Тернопільського державного медичного університету імені І. Я. Горбачевського.
Токсичне ураження печінки викликали внутрішньоочеревинним введеням $50 \%$ олійного розчину тетрахлорметану в дозі $1,0 \mathrm{mл/кг} \mathrm{[8].}$ Гостре адреналінове пошкодження міокарда спричиняли шляхом одноразового внутрішньом'язового уведення $0,18 \%$ розчину адреналіну гідротартрату (“Дарниця", Укра на) в дозі 0,5 мг/кг [3]. Евтаназію проводили з використанням тіопенталу натрію на 3-тю, 24-ту та 48-му години після введення адреналіну на фоні 7-о доби гострого токсичного гепатиту. Кров забирали із серця тварин. Дослідженням піддавали міокард, печінку, кров та сироватку крові дослідних та контрольних тварин (інтактні).

У вищевказаних тканин визначали активність мітохондріальних ферментів сукцинатдегідрогенази [2] та цитохромоксидази [5], як показників енергозабезпечувального окиснення. Оцінку стану вуглеводного обміну проводили шляхом дослідження динаміки рівня головних донаторів енергі в клітині - глюкози і глікогену [1]. Усі експерименти виконано із дотриманням загальних правил і положень Європейсько Конвенці із захисту хребетних тварин, яких використовують для дослідницьких та інших наукових цілей (Страсбург, 1986), Загальних етичних принципів експериментів на тваринах (Ки в, 2001) [4, 9]. Статистичну обробку результатів дослідження здійснювали за допомогою методів варіаційно статистики з використанням критерію Стюдента [7].

Результати й обговорення. Нами встановлено, що на фоні сьомо доби гострого тетрахлорметанового гепатиту через три години після введення токсично дози адреналіну відмічається посилення процесу глікогенолізу, про що свідчить зменшення кількості глікогену в тканині печінки на $13,8 \%$, у порівнянні з інтактною групою (рис. 1). У подальшому даний процес продовжувався і в терміні 24 і 48 год адреналінового ураження кількість глікогену знизилася на 23,1 і 27,3\% 
Оеляди літератури, оригінальні дослідження, поеляд на проблему

відповідно. У тканині міокарда спостерігалася подібна тенденція і в терміні 3 години кількість глікогену знизилася на $36,5 \%$ у порівнянні 3 контролем, в терміні 24 і 48 годин - на 50,6 і 56,4 \% відповідно.
При визначенні концентраці глюкози в сироватці крові максимальне підвищення відмічалося через 3 години після гострого адреналінового ураження. У цьому терміні даний показник був вищий від контролю в 1,8 раза (рис. 2).

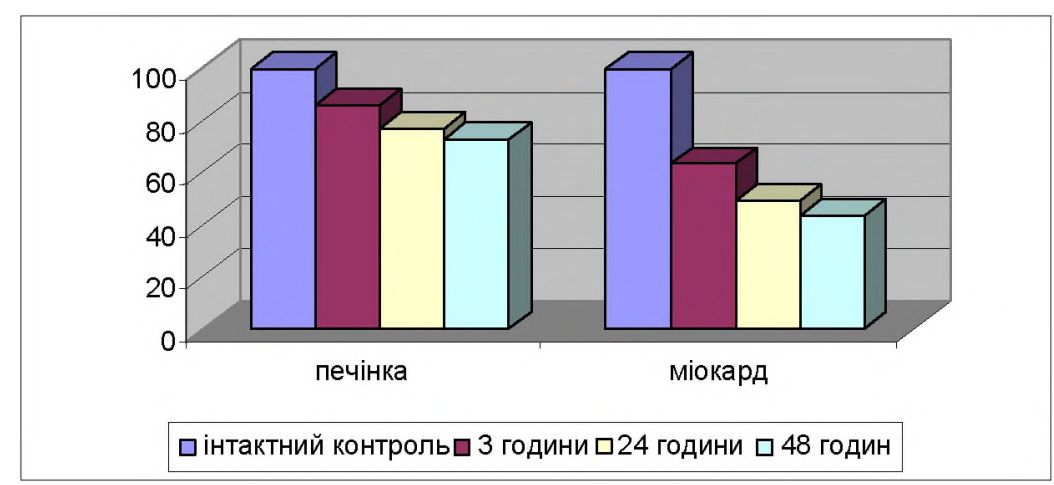

Рис. 1. Динаміка вмісту глікогену в гомогенатах міокарда та печінки щурів, уражених токсичними дозами адреналіну, на 7-му добу гострого тетрахлорметанового гепатиту, \%

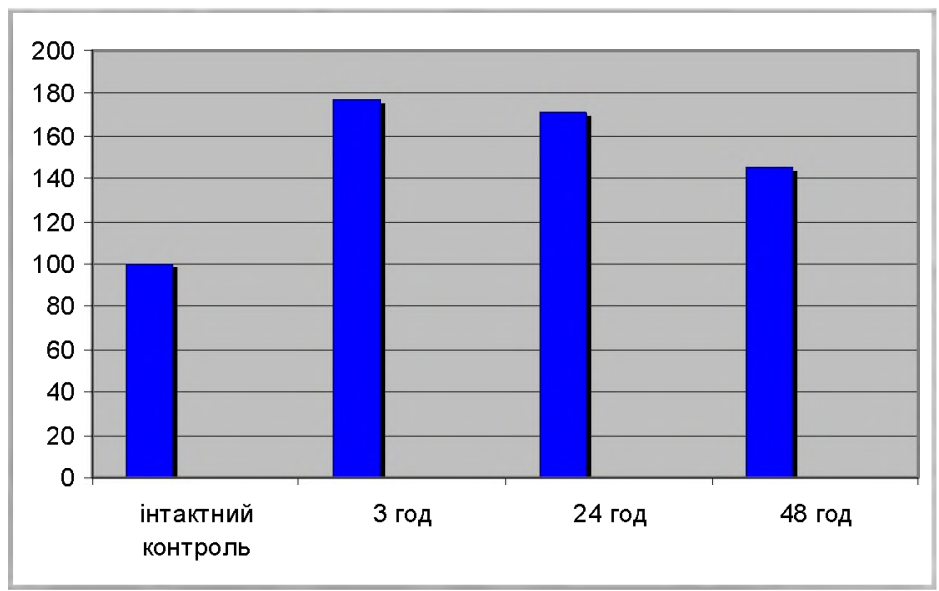

Рис. 2. Динаміка концентраці глюкози в сироватці крові уражених щурів, \%.

Надалі концентрація глюкози поступово знижувалася, проте залишалася вищою від контролю в 1,7 раза в терміні 24 години і в 1,5 раза в терміні 48 годин. Така динаміка вищезгаданих показників підтверджує значне виснаження запасів енергоємних субстратів при змодельованому патологічному стані.

Важливе місце в енергетичному забезпеченні клітини належить цитохромоксидазі - кінцевому
Ферменту дихального ланцюга, який забезпечує перенесення електронів від цитохрому на кисень. Активність цитохромоксидази за умов даного поєднаного ураження зазнавала різкого пригнічення, порівняно з інтактною групою. У сироватці крові встановлено зниження активності даного ензиму на $36 \%$ в терміні 3 години, і наступне зниження на $48 \%$ і 53 \% від контролю в терміні 24 і 48 годин (табл. 1).

Таблиця 1. Активність цитохромоксидази у сироватці крові (ммоль/л·хв), міокарді та печінці (ммоль/кг·хв) щурів, уражених тетрахлорметаном та адреналіном (M $\pm m ; n=24)$

\begin{tabular}{|l|c|c|c|c|}
\hline \multicolumn{1}{|c|}{ Групи тварин } & $\begin{array}{c}\text { Інтактний } \\
\text { контроль }\end{array}$ & $\begin{array}{c}\mathrm{CCL}_{4} 7 \text {-ма доба }+ \\
\text { адреналін } \\
3 \text { год }\end{array}$ & $\begin{array}{c}\mathrm{CCL}_{4} 7 \text {-ма доба }+ \\
\text { адреналін } \\
24 \text { год }\end{array}$ & $\begin{array}{c}\mathrm{CCL}_{4} 7 \text {-ма доба+ } \\
\text { адреналін } \\
48 \text { год }\end{array}$ \\
\hline Сироватка крові & $6,70 \pm 0,06$ & $6,27 \pm 0,15^{*}$ & $5,93 \pm 0,05^{*}$ & $5,85 \pm 0,03^{*}$ \\
\hline Міокард & $10,96 \pm 0,28$ & $7,35 \pm 0,31^{*}$ & $6,79 \pm 0,04^{*}$ & $6,57 \pm 0,14^{*}$ \\
\hline Печінка & $9,45 \pm 0,18$ & $7,07 \pm 0,14^{*}$ & $6,70 \pm 0,07^{*}$ & $6,50 \pm 0,06^{*}$ \\
\hline
\end{tabular}

Примітка: * - вірогідні зміни між тваринами інтактного контролю та ураженими адреналіном та тетрахлорметаном 
Оеляди літератури, ориаінальні дослідження, поеляд на проблему

Подібна закономірність відстежувалася при дослідженні активності цитохромоксидази у печінці, в якій вона була меншою в 2,3 раза на третю годину після введення адреналіну і в 2,8 та 3 рази на 24-ту і 48-му години, порівняно з інтактною групою. У міокарді також спостерігалося пригнічення активності даного ензиму і вона прогресуюче знижувалася в 2,6 раза, 3,5 раза і в 4 рази в терміні 3 , 24 і 48 годин відповідно, порівняно з контролем.

Для детальнішого вивчення перебігу процесів тканинного дихання нами було досліджено активність ще одного мітохондріального ензиму - сукцинатдегідрогенази. Так, в терміні 3 години після введення адреналіну активність даного ферменту в сироватці крові знизилася на $27,2 \%$, максималь- не зниження активності відмічалось в терміні 24 години і було нижчим від контролю на $36 \%$, в подальшому цей показник дещо зріс, проте залишався нижчим від контролю на 23 \% (табл. 2). Дана закономірність утримувалася і при дослідженні активності вказаного ферменту в печінці, де цей показник був менший в 1,1 і 1,6 раза на 3 -тю і 24 ту години дослідження, а згодом дещо підвищився, проте залишався нижчим від контролю в 1,5 раза. У міокарді активність сукцинатдегідрогенази менш виражено, проте також знижувалася через 3 години після введення адреналіну - на 4,4 \%, максимально в терміні 24 години - на 17,8 \% і надалі на 48-мій годині дослідження залишалася нижчою від контролю на $16,7 \%$.

Таблиця 2. Активність сукцинатдегідрогенази у сироватці крові (ммоль/л·хв), міокарді та печінці (ммоль/кг·хв)

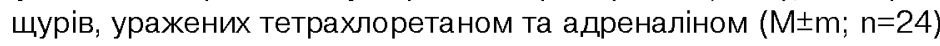

\begin{tabular}{|l|c|c|c|c|}
\hline $\begin{array}{c}\text { Групи } \\
\text { тварин }\end{array}$ & $\begin{array}{c}\text { Інтактний } \\
\text { контроль }\end{array}$ & $\begin{array}{c}\mathrm{CCL}_{4} \text { 7-ма доба }+ \\
\text { адреналін } \\
\text { 3 год }\end{array}$ & $\begin{array}{c}\mathrm{CCL}_{4} \text { 7-ма доба } \\
\text { адреналін } \\
24 \text { год }\end{array}$ & $\begin{array}{c}\mathrm{CCL}_{4} \text { 7-ма доба } \\
\text { адреналін } \\
48 \text { год }\end{array}$ \\
\hline Сироватка крові & $9,23 \pm 0,09$ & $6,80 \pm 0,33^{*}$ & $6,52 \pm 0,33^{*}$ & $7,22 \pm 0,44^{*}$ \\
\hline Міокард & $9,07 \pm 0,17$ & $8,68 \pm 0,14$ & $7,52 \pm 0,15^{*}$ & $7,56 \pm 0,06$ \\
\hline Печінка & $6,73 \pm 0,10$ & $5,95 \pm 0,19^{*}$ & $4,18 \pm 0,08^{*}$ & $4,53 \pm 0,11^{*}$ \\
\hline
\end{tabular}

Динаміка активності даних показників верифікує порушення ферментативно активності енергетичних процесів в умовах змодельованого поєднаного патологічного стану.

Висновки. Одночасне ураження щурів тетрахлорметаном та токсичними дозами адреналіну призводить до збільшення вмісту глюкози в сиро- ватці крові щурів та зменшення вмісту глікогену у печінці та міокарді. Це супроводжується зниженням активності ферментів, що забезпечують біоенергетичні процеси в організмі. Нами встановлено зниження активності сукцинатдегідрогенази та цитохромоксидази у досліджуваних органах після ураження впродовж всього експерименту.

\section{ЛІТЕРАТУРА}

1. Біологічна хімія : лабораторний практикум : навч. посібник для студ. вищ. навч. закл. 3-4 рівн. акредитаці / за ред. Я. І. Гонського. - Тернопіль : Укрмедкнига, 2001. $288 \mathrm{c}$.

2. Ещенко Н. Д. Определение количества янтарной кислоты иактивности сукцинатдегидрогеназы / Н. Д. Ещенко, Г. Г. Вольский // Методы биохимических исследований. - Л. : Изд-во Ленинградского университета, 1982. С. 207-210.

3. Ігрунова К. М. Корекція енергообміну при патологі міокарда / К. М. Ігрунова, Л. П. Ігрунов // Експериментальна та клінічна ензимологія. - 1995. - С. 160161.

4. Использование лабораторных животных в токсикологическом експерименте (методические рекомендации); под. ред. . проф., академика РАМН П. И. Сидорова. - Архангельск, 2002. - 84 с.
5. Кривченкова Р. С. Определение активности цитохромоксидазы в суспензии митохондрий / Р. С. Кривченкова // Современные методы в биохимии. - М. : Медицина, 1977. - С. 47-49.

6. Кушаковский М. С. Метаболические болезни сердца / М. С. Кушаковский. - СПб. : Фолиант, 2000. - 128 с.

7. Лапач С. Н. Статистические методы в медикобиологических исследованиях с использованием Exel/ С. Н. Лапач, А. В. Чубенко, П. Н. Бабич. - К. : Морион, 2000. $-320 \mathrm{c}$.

8. Состояние дыхательной цепи митохондрий печени крыс с експериментальным токсическим гепатитом / А. П. Ширяева, Е. В. Байдюк, А. В. Аркадьева [и др.] // Цитология. - 2007. - Т. 49, № 2. - С. 52-54.

9 . European convention for the protection of vertebrate animals used for experiment and other scientific purposes. Council of Europe, Strasburg, 1986. - 56 p. 
Оеляди літератури, оригінальні дослідження, поеляд на проблему

\title{
CHANGING OF BIOENERGY PROCESSES INDICATORS PROVIDED BY SIMULTANEOUS INJURY OF RATS WITH TOXIC DOSES OF ADRENALINE AND CARBON TETRACHLORIDE
}

\author{
๑K. O. Aleksevych, I. S. Fira, O. I. Hrymalyuk \\ SHEI «Ternopil State Medical University by I.Ya. Horbachevsky of MPH of Ukraine» \\ SUMMARY. Established that the simultaneous injury of rats with carbon tetrachloride and adrenaline causes increased \\ glycogenolysis process, as indicated by the increase in blood glucose and reducing the amount of glycogen in the organs of \\ animals. During the experiment we observed decreased activity of succinate dehydrogenase and cytochrome oxidase, \\ KEY WORDS: carbon tetrachloride, epinephrine, glucose, glycogen, succinate dehydrogenase, cytochrome oxidase.
} indicating inhibition of bioenergetic processes in rats after lesion.

Отримано 5.02.2015 